\title{
Stem Photosynthesis Affects Hydraulic Resilience in the Deciduous Populus alba but Not in the Evergreen Laurus nobilis
}

\author{
Patrizia Trifilò $^{1, *}$, Sara Natale ${ }^{2}\left(\mathbb{0}\right.$, Sara Gargiulo $^{3}$, Elisa Abate ${ }^{1}$, Valentino Casolo ${ }^{3}$ and Andrea Nardini ${ }^{2}$ \\ 1 Dipartimento di Scienze Chimiche, Biologiche, Farmaceutiche ed Ambientali, Università di Messina, \\ Salita Stagno D, Alcontres, 31, 98166 Messina, Italy; elisa.abate@unime.it \\ 2 Dipartimento di Scienze della Vita, Università di Trieste, Via L. Giorgieri, 10, 34127 Trieste, Italy; \\ sara.natale@phd.units.it (S.N.); nardini@units.it (A.N.) \\ 3 Dipartimento di Scienze AgroAlimentari, Ambientali e Animali, Università di Udine, Via delle Scienze, 91, \\ 33100 Udine, Italy; gargiulo.sara@spes.uniud.it (S.G.); valentino.casolo@uniud.it (V.C.) \\ * Correspondence: ptrifilo@unime.it
}

check for

updates

Citation: Trifilò, P.; Natale, S.; Gargiulo, S.; Abate, E.; Casolo, V.; Nardini, A. Stem Photosynthesis Affects Hydraulic Resilience in the Deciduous Populus alba but Not in the Evergreen Laurus nobilis. Water 2021, 13, 2911. https://doi.org/10.3390/ w13202911

Academic Editor: Teresa Afonso do Paço

Received: 27 September 2021

Accepted: 14 October 2021

Published: 16 October 2021

Publisher's Note: MDPI stays neutral with regard to jurisdictional claims in published maps and institutional affiliations.

Copyright: (c) 2021 by the authors. Licensee MDPI, Basel, Switzerland. This article is an open access article distributed under the terms and conditions of the Creative Commons Attribution (CC BY) license (https:/ / creativecommons.org/licenses/by/ $4.0 /)$.

\begin{abstract}
Stem photosynthesis has been suggested to play relevant roles to cope with different biotic and abiotic stress factors, including drought. In the present study, we performed measurements of stem hydraulic conductance and non-structural carbohydrate content in the evergreen Laurus nobilis L. and the deciduous Populus alba L., subjected to inhibition of stem photosynthesis and successive exposure to a drought-recovery cycle in order to check if stem photosynthesis may be involved in allowing hydraulic recovery after drought stress relief. Stem shading affected the growth of L. nobilis but not of P. alba saplings. By contrast, inhibition of stem photosynthesis was coupled to inhibition of hydraulic recovery following embolism build-up under drought in P. alba but not in L. nobilis. The two study species showed a different content and behavior of nonstructural carbohydrates (NSCs). The differences in NSCs' trend and embolism reversal ability led to a significant relationship between starch content and the corresponding hydraulic conductance values in L. nobilis but not in P. alba. Our findings suggest that stem photosynthesis plays a key role in the maintenance of hydraulic functioning during drought especially in the deciduous species. This, in turn, may increase their vulnerability under current global climate change scenarios.
\end{abstract}

Keywords: deciduous; drought; evergreen; hydraulic recovery; laurel; poplar; nonstructural carbohydrates; starch; sugars; xylem embolism

\section{Introduction}

Most terrestrial plants perform photosynthesis at the leaf level, but some of them can only use stems to this purpose, as leaves have been eliminated or transformed into thorns or other organs serving different functions in peculiar habitats. However, even several leaf-bearing plants, including both herbaceous and woody species, do assimilate $\mathrm{CO}_{2}$ at stem level, as suggested by the presence of chloroplasts in the bark and even in wood parenchyma and pith [1-4]. Photosynthetic activity of stems has been reported in many species and families, encompassing their biogeographic and phylogenetic features [5-7].

In trees and other woody plants, carbon assimilation is typically higher in currentyear stems compared to older ones [8]. The actual contribution of stem photosynthesis to plant carbon balance, compared to carbon uptake at leaf level, remains debated [7,9-13]. Different studies have suggested that carbon assimilation by tree stems can provide different functional advantages for plants. The increased carbon gain would offer additional carbohydrate availability for the production of new leaves, flowers and fruits under both optimal and stressful environmental conditions [3,14-19]. In accordance, different studies have shown that stem photosynthesis contributes to stem growth and bud development, especially in young woody plants and in deciduous species [20-24]. Photosynthetic activity of stems also plays a relevant role to cope with defoliation caused by biotic or abiotic 
agents [25-27]. Finally, it contributes to face thermal stress [8,28-32] and drought, as reported in different desert and semi-desert non-succulent species, as well as in Mediterranean plants (i.e., $[4,5,8,10-12,33,34]$ ).

Research on stem photosynthesis has recently received renewed interest because of its potential role in resistance and resilience of plants to severe global change-type droughts [35]. Hydraulic failure caused by massive xylem embolism is a major and recurrent cause of drought-induced tree mortality [36-38], with an additional role suggested for carbon starvation. Interestingly, carbohydrate content decline, even when non-lethal, has been reported to impact plant hydraulic efficiency [39-43]. Non-structural carbohydrates (NSCs) are apparently involved in the maintenance of plant hydraulic function via different processes, which are only partially understood. NSCs are involved in xylogenesis, thus providing plants with the possibility to grow new xylem to increase or maintain their hydraulic capacity, despite possible occurrence of xylem embolism or mechanical damage impairing older conduits $[44,45]$. Moreover, NSCs are also involved in osmoregulation processes that, at the level of wood parenchyma, might protect cells from damage caused by drought- or freeze-induced protoplast dehydration [46-48].

Besides the relatively well-known role of NSCs in xylem growth and symplast osmoregulation, NSCs stored in wood parenchyma have also been reported to be involved in lowering the osmotic potential of xylem sap during and after stressful events. Xylem sap osmoregulation by soluble NSCs might lead to lowering its freezing point, thus limiting formation of ice in xylem conduits during freeze stress [49,50]. Accumulation of soluble NSCs in the xylem sap during and/or after freeze or drought stress might also provide the necessary driving force to refill embolized conduits with water once stress is relieved and the xylem pressure rises to near-atmospheric values [41,42,51-55]. An additional intriguing role of NSCs might be the direct or indirect contribution to the production of surfactants that, by modifying xylem sap surface tension or stabilizing gas nanobubbles, would modify the xylem vulnerability to embolism formation on diurnal or seasonal time scales [55-58].

Based on the above, stem-level photosynthesis might play a primary role not only in the production of NSCs contributing to the whole plant carbon gain but also in the modulation and regulation of xylem hydraulic function. Indeed, some recent studies have reported experimental evidence for a role of stem photosynthesis in reducing xylem vulnerability to embolism and improving the capacity for xylem embolism reversal [59-63].

In the present study, we report measurements of stem hydraulic conductance in response to drought stress and re-irrigation in plants subjected to inhibition of stem photosynthesis via localized shading. We aimed at testing the hypotheses that the carbon gain obtained by stem photosynthesis is involved in allowing hydraulic recovery after drought stress relief. We focused on two woody species, namely the evergreen Laurus nobilis L. and the deciduous Populus alba $\mathrm{L}$, because, for both of them, there is available experimental evidence suggesting their capacity to reverse xylem embolism following drought stress, with an involvement of NSC stores [55,64].

\section{Materials and Methods}

\subsection{Plant Material and Growth Condition}

Measurements were performed during spring and summer 2019 on P. alba and L. nobilis saplings (50 samples per species). In April, one-year-old cuttings of P. alba and L. nobilis growing in 4-liter pots were transferred to a greenhouse at University of Messina, Italy. Samples were randomly divided in two experimental groups: control (C) and shaded (S) samples. In $S$ samples, the main stem and any lateral branch were wrapped with aluminum foil, similarly to the experimental procedure described by Saveyn et al. [20]. This treatment was expected to significantly reduce the presence of differentiated chloroplasts and, in any case, to inhibit stem photosynthesis, without blocking gas exchange between stem tissues and atmosphere [20,59].

In the greenhouse, plants received only natural light, with maximum photosynthetic photon flux density (PPFD) daily values averaging $1050 \pm 180 \mu \mathrm{mol} \mathrm{s}^{-1} \mathrm{~m}^{-2}$. Air tempera- 
ture ranged from $22 \pm 2{ }^{\circ} \mathrm{C}$ to $31 \pm 3{ }^{\circ} \mathrm{C}$ (night/day) and the mean value of air humidity was $80 \pm 3 \%$. All plants were regularly irrigated to field capacity (FC), every second day from April until early June, when the drought treatment was imposed (Figure 1). The drought treatment started after stem and leaf production and growth had ceased. Water stress was imposed by irrigating plants to 30\% FC once per week, for 4 weeks (drought period). This irrigation regime induced a strong reduction of gas exchange and xylem water potential $\left(\Psi_{\mathrm{x}}\right)$, thus inducing substantial loss of stem hydraulic conductivity (see below). After the drought period, C and S samples were further divided in two groups. A first set of plants was used to immediately measure different physiological parameters (see below) at the end of drought. A second group of samples was re-irrigated to field capacity and measured 7 days later.

\section{A: Experimental design}

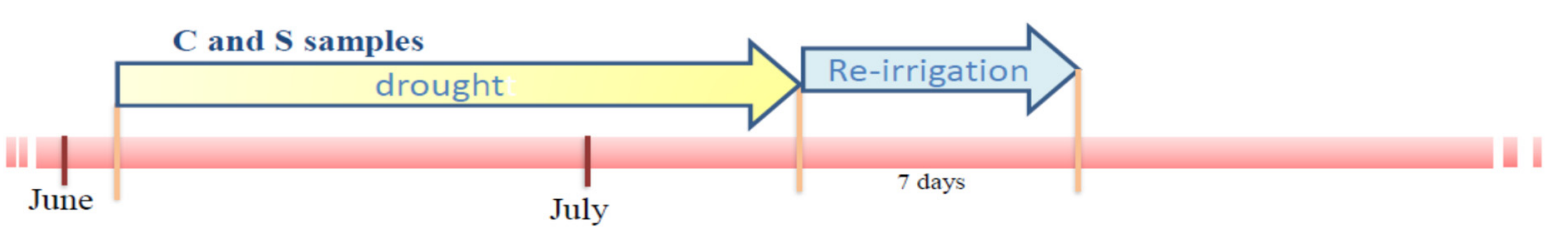

\section{B: Measurements}

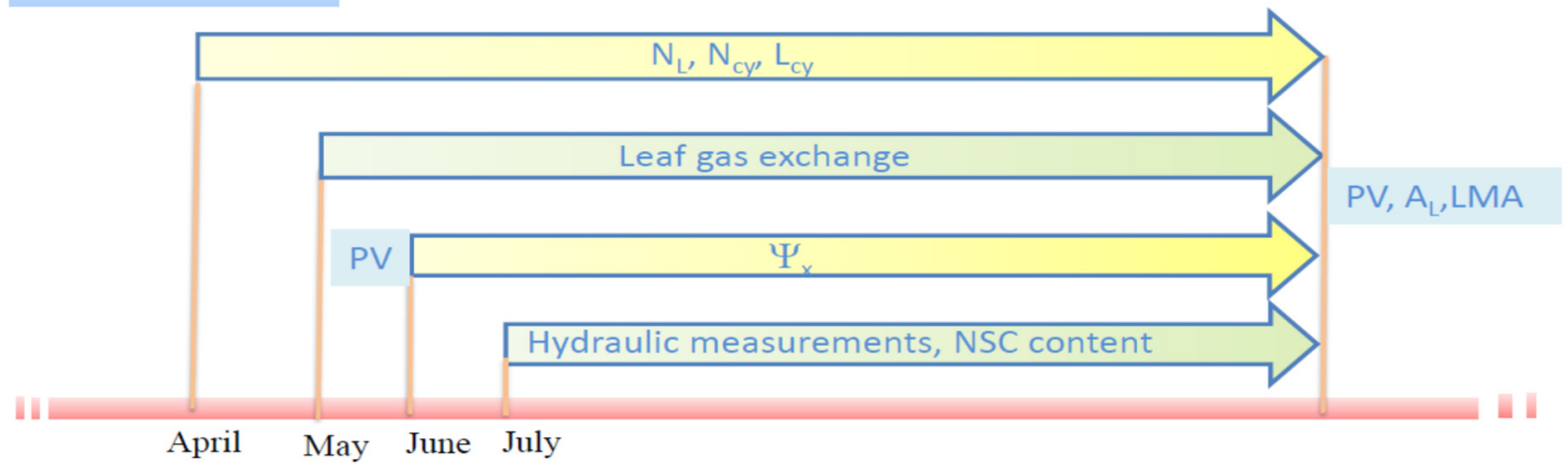

Figure 1. (A) Experimental design and (B) measurements performed on control and stem-shaded samples (C and S, respectively) of L. nobilis and P. alba plants; (A) At the beginning of June, C and S samples were subjected to a water stress treatment. One month later, a set of samples was measured for different physiological parameters. Another set of plants was re-irrigated at field capacity and measured after 7 days to evaluate the capacity for recovery; (B) Leaf gas exchange rates were measured from May to the end of the experiment; xylem water potential $\left(\Psi_{\mathrm{x}}\right)$ values were recorded from June to the end of experiments; hydraulic measurements and NSC content were performed after the drought treatment and 7 days after re-irrigation. Moreover, PV-curves were measured before and at the end of the drought-recovery treatments. Leaf area and leaf mass per area were measured at the end of the experiments (for details, see the text). PV: pressure volume curves; $\mathrm{N}_{\mathrm{L}}$ : number of leaves of the current-year branches; $\mathrm{N}_{c y}$ : number of current-year branches; $\mathrm{L}_{c y}$ : length of the current-year branches; $\mathrm{A}_{\mathrm{L}}$ : leaf area; LMA: leaf mass area.

Moreover, five additional plants per species were maintained fully irrigated during the whole experimental period and grew under the same environmental conditions experienced by $C$ and S samples. These plants were used to collect samples for estimating NSC content (see below) in plants not experiencing drought.

\subsection{Morphological Measurements}

To estimate the possible effect of stem shading on plant growth, the number $\left(\mathrm{N}_{\mathrm{cy}}\right)$ and the length $\left(\mathrm{L}_{\mathrm{cy}}\right.$, as recorded by a ruler) of current-year stems as well as the total number of leaves on current-year branches $\left(\mathrm{N}_{\mathrm{L}}\right)$ were measured weekly during the whole experimental period (i.e., from April to July) in $3 \mathrm{C}$ and $3 \mathrm{~S}$ samples per species. 
Leaf area $\left(A_{L}\right)$ and leaf mass per unit area (LMA) were estimated on 40 leaves randomly collected at the end of hydraulic measurements (see below). $\mathrm{A}_{\mathrm{L}}$ was recorded by a scanner (HP Scanjet G4050, Palo Alto, CA, USA) and image analysis based on the software ImageJ (http: / /imagej.nih.gov/ij/, accessed on 8 October 2021). Leaves were oven-dried for 3 days at $70{ }^{\circ} \mathrm{C}$ to obtain their dry weight (DW) and the leaf mass per unit area (LMA) was calculated as $\mathrm{DW} / \mathrm{A}_{\mathrm{L}}$.

\subsection{Leaf Water Potential Isotherms}

At the beginning of June (i.e., before starting the drought treatment) and in July (i.e., after one month of water stress), leaf water potential isotherms (PV-curves) were performed on $5 \mathrm{C}$ and $5 \mathrm{~S}$ leaves per species and per treatment, sampled from different plants. PVcurves were elaborated to obtain the leaf water potential at the turgor loss point $\left(\Psi_{\text {tlp }}\right)$, the osmotic potential at full turgor $\left(\pi_{0}\right)$, and the bulk modulus of elasticity $\left(\varepsilon_{\max }\right)$. In particular, $\Psi_{\text {tlp }}$ was estimated as the flex point of the relationship between $1 / \Psi_{\mathrm{L}}$ and water loss, $\pi_{0}$ was calculated by the $y$-intercept of the linear region of this relationship, and $\varepsilon_{\max }$ was calculated by the ratio between the change of turgor pressure and the relative change of the leaf water content [65].

\subsection{Gas Exchange and Water Potential Measurements}

In order to check gas exchange rates and water status in $C$ versus $S$ samples under drought and recovery, leaf conductance to water vapor $\left(g_{L}\right)$ and photosynthetic rate $\left(A_{n}\right)$ were measured from the beginning of May (i.e., when fully expanded leaves of poplar samples were observed) to the end of the experiment (Figure 1). $g_{L}$ and $A_{n}$ were measured once per week until the beginning of the drought treatment and, afterwards, twice per week. Measurements were performed at midday on at least 4 leaves per group and per treatment, selected from different plants, using a portable LCi Analyzer System (ADC Bioscientific Ltd., Herts, UK). To avoid excessive defoliation, minimum diurnal xylem water potential $\left(\Psi_{\mathrm{x}}\right)$ was measured at midday only the week before starting the drought treatment, and then on the same days of gas exchange measurements. This experimental procedure allowed us to check that the applied water stress led plants to experience $\Psi_{\mathrm{X}}$ values of about $-1.5 \mathrm{MPa}$ (i.e., $\Psi_{\mathrm{X}}$ inducing significant loss of hydraulic conductivity for both species $[66,67])$. $\Psi_{\mathrm{x}}$ was also measured at midday and in the morning (at about 6:00 a.m.) on the same samples used for hydraulic measurements. Measurements of $\Psi_{\mathrm{X}}$ were performed on 3 leaves from different plants per species and per treatment, using a portable pressure chamber (3005 Plant Water Status Console, Soilmoisture Equipment Corp., Goleta, CA, USA). Leaves were wrapped in cling film and aluminum foil 2-3 h before sampling.

\subsection{Hydraulic Conductivity Measurements}

Xylem-specific hydraulic conductivity $\left(\mathrm{K}_{\mathrm{x}}\right)$ was measured in $\mathrm{C}$ and $\mathrm{S}$ samples after the drought period and upon recovery. Measurements were performed at midday (i.e., 12.00) and on the following morning (i.e., 6:00 a.m.) on about $10 \mathrm{~cm}$-long current-year samples using a hydraulic apparatus [68,69]. Perfusion solution was a commercial mineral water in which were added $15 \mathrm{mM} \mathrm{KCl}$ [70]. Samples were perfused at a pressure $(\mathrm{P})$ of $8 \mathrm{kPa}$. When flow rate $(\mathrm{F})$ became stable, samples were flushed at $\mathrm{P}=0.2 \mathrm{MPa}$ for $15 \mathrm{~min}$ to remove embolism and $F$ was re-measured at $8 \mathrm{kPa}$. $\mathrm{K}_{\mathrm{x}}$ was computed as $(\mathrm{F} / \mathrm{P}) \times\left(\mathrm{L} / \mathrm{A}_{\mathrm{x}}\right)$, where $\mathrm{L}$ is sample length and $\mathrm{A}_{\mathrm{x}}$ is the xylem cross-sectional area. The initial branch hydraulic conductivity value $(\mathrm{K})$ and the $\mathrm{K}$ value measured after embolism removal $\left(\mathrm{K}_{\max }\right)$ were used to estimate the PLC as PLC $=1-\left(\mathrm{K} / \mathrm{K}_{\max }\right) \times 100$.

To avoid possible cutting artifacts [71], $1 \mathrm{~h}$ before their collection, branches were girdled for their entire length at about $3 \mathrm{~cm}$ intervals, by removing about $3 \mathrm{~mm}$ wide bark rings. The exposed wood was immediately covered with a thin layer of silicone grease to avoid desiccation. After girdling, at least six samples per treatment per species were cut under water and maintained with their cut end immersed into the water for $1 \mathrm{~h}$ in order to 
relax xylem tension [72]. Then, the current-year segment was collected and measured. All hydraulic measurements were performed at a temperature of $20^{\circ} \mathrm{C}$.

\subsection{NSC Content}

At least 5 samples from those used for hydraulic measurements were collected to estimate NSC content (sugars and starch). Moreover, at the end of drought treatment, five additional samples were collected from samples maintained fully irrigated during the whole experimental period and growing under the same environmental conditions experienced by $\mathrm{C}$ and $\mathrm{S}$ samples. After hydraulic measurements, stem samples were immediately microwaved at $700 \mathrm{~W}$ for $3 \mathrm{~min}$ to stop enzymatic activities, oven-dried at $70{ }^{\circ} \mathrm{C}$ for $24 \mathrm{~h}$, and finally grounded to fine powder (particle size $<0.15 \mathrm{~mm}$ ). NSC extraction followed the standardized method proposed by Quentin et al. [73] and Landhausser et al. [74], with minor modifications to account for small amount of material. An aliquot of $15 \pm 1 \mathrm{mg}$ of dry sample was suspended in $0.5 \mathrm{~mL}$ of ethanol $80 \%(\mathrm{v} / \mathrm{v})$, incubated at $80{ }^{\circ} \mathrm{C}$ for $30 \mathrm{~min}$ and centrifuged (with Mikro 120, Hettuch zentrifugen, Tuttlingen, Germany) at 14.000 RPM for three minutes. This step was repeated, suspending the pellet with $0.3 \mathrm{~mL}$ of ethanol $80 \%$. Once mixed in the same Eppendorf tube, the extracts were dried till complete evaporation. The resulting crystalized carbohydrates were re-suspended with $0.5 \mathrm{~mL}$ of $50 \mathrm{mM}$ Tris- $\mathrm{HCl}$ pH 7.5 and centrifuged at $14.000 \mathrm{RPM}$ for three minutes. Sugars contained in supernatants were measured with Anthrone assay [75], using spectrophotometer at wavelength of $620 \mathrm{~nm}$. The absorbance values were converted to $\mathrm{mg}_{\text {glucose }} \mathrm{g}^{-1} \mathrm{DW}$ using a calibration curve prepared with known amounts of glucose. Pellets were resuspended in $1 \mathrm{~mL}$ of $0.2 \mathrm{M}$ Sodium Acetate Trihydrate $\mathrm{pH} 4.6$ and incubated at $100{ }^{\circ} \mathrm{C}$ for $1 \mathrm{~h}$ to allow starch gelatinization. The enzymatic hydrolysis-using $100 \mathrm{U}$ of $\alpha$-amylase and $25 \mathrm{U}$ of amyloglucosidase per sample-was performed at $55^{\circ} \mathrm{C}$. To stop enzymatic activity, samples were boiled for $5 \mathrm{~min}$. Glucose obtained from starch digestion was evaluated as NADPH (absorbance at $340 \mathrm{~nm}$ ) by action of $0.3 \mathrm{U}$ per sample of hexokinase and $0.5 \mathrm{U}$ per sample of glucose-6-phosphate-deihydrogenase in $0.1 \mathrm{~mL}$ of buffer solution $(50 \mathrm{mM}$ Tris- $\mathrm{HCl}, 2 \mathrm{M} \mathrm{MgCl}_{2}, 50 \mathrm{mM} \mathrm{NADP}^{+}$and $0.4 \mathrm{M} \mathrm{ATP}$ ) at $32{ }^{\circ} \mathrm{C}$ for $20 \mathrm{~min}$. Starch content $\left(\mathrm{mg} \mathrm{g}^{-1} \mathrm{DW}\right)$ was calculated comparing NADPH obtained with known amounts of commercial amylose from potato (Sigma-Aldrich, Milan, Italy) that followed the same hydrolysis protocol of samples. Spectrophotometer analysis was performed in a VICTOR3 Multilabel Counter Plate Reader (Perkin Elmer, Boston, MA, USA), for both sugars and starch, using $300 \mu \mathrm{L}$ per sample.

\subsection{Statistical Analysis}

All statistical analyses were performed with SigmaStat v. 12.0 (SPSS, Inc., Chicago, IL, USA). To test for differences between $C$ and $S$ samples in terms of $\mathrm{N}_{\mathrm{cy}}, \mathrm{L}_{\mathrm{cy}}, \mathrm{A}_{\mathrm{L}}$ and LMA for each species, a Student's $t$-test $(\alpha=0.05)$ was performed after checking for normality assumption. Effects of stem shading and drought on $\mathrm{N}_{\mathrm{L}}$, gas exchange, water status, PVcurve data, PLC and NSC were assessed by two-way ANOVA. For statistically significant tests $(p<0.05)$, a Tukey's post hoc test using Holm-Sidak $p$-values correction was carried out to perform pairwise comparisons.

\section{Results}

\subsection{Stem Shading Effects on Plant Growth}

Plant growth ceased by the end of May, and no further production of branches and leaves was observed until the end of the experiment (July) in both L. nobilis and P. alba. Table 1 reports data of $\mathrm{N}_{\mathrm{cy}}, \mathrm{L}_{\mathrm{cy}}, \mathrm{A}_{\mathrm{L}}$ and LMA as recorded at the end of the experimental period. Stem shading did not affect the growth of P. alba. In fact, the number and length of current-year branches were similar in $C$ and $S$ samples (Table 1). Similarly, no differences were recorded in terms of mean $\mathrm{A}_{\mathrm{L}}\left(\sim 17 \mathrm{~cm}^{2}\right)$ and LMA $\left(\sim 42 \mathrm{mg} \mathrm{cm}^{-2}\right)$ in this species. By contrast, $\mathrm{S}$ samples of $L$. nobilis showed significantly lower values of $A_{L}$ compared to C plants (10.6 \pm 3 versus $12.2 \pm 3.2 \mathrm{~cm}^{2}$, respectively), but similar values of $\mathrm{N}_{\mathrm{cy}}, \mathrm{L}_{\mathrm{cy}}$ and 
LMA. The drought treatment affected the number of leaves per plant in P. alba but not in L. nobilis, and $\mathrm{N}_{\mathrm{L}}$ decreased more in $\mathrm{C}$ than in $\mathrm{S}$ poplar (Table 2). This decrease was due to leaf shedding in response to water stress. No leaf fall was observed over the same time interval in well-watered poplar samples used for NSC estimation (see above).

Table 1. Mean \pm SEM of the total number $\left(\mathrm{N}_{\mathrm{cy}}\right)$ and length $\left(\mathrm{L}_{\mathrm{cy}}\right)$ of current-year branches, mean leaf surface area $\left(A_{L}\right)$ and leaf mass per area (LMA) as recorded in control (C) and shaded (S) samples of L. nobilis and P. alba. Differences between $C$ and S samples were checked by a Student's $t$-test. $p$-Values are reported between brackets; $\mathrm{n}=3$ plants for $\mathrm{N}_{c y}$ and $\mathrm{L}_{c y} ; \mathrm{n}=40$ leaf samples for $\mathrm{A}_{\mathrm{L}}$ and LMA.

\begin{tabular}{|c|c|c|c|c|}
\hline \multirow{2}{*}{ Parameter } & \multicolumn{2}{|c|}{ L. nobilis } & \multicolumn{2}{|c|}{ P. alba } \\
\hline & C & $\mathbf{S}$ & C & $\mathbf{S}$ \\
\hline \multirow{2}{*}{$\mathrm{N}_{\mathrm{cy}}$} & $2.7 \pm 0.3$ & $2.7 \pm 0.3$ & $7.7 \pm 1.1$ & $9.3 \pm 1.9$ \\
\hline & \multicolumn{2}{|c|}{$(p$-value $=1.0)$} & \multicolumn{2}{|c|}{$(p$-value $=0.292)$} \\
\hline \multirow{2}{*}{$\mathrm{L}_{\mathrm{cy}}(\mathrm{cm})$} & $13.3 \pm 0.9$ & $13.4 \pm 2.3$ & $17.6 \pm 3.1$ & $13.7 \pm 1.7$ \\
\hline & \multicolumn{2}{|c|}{$(p$-value $=1.0)$} & \multicolumn{2}{|c|}{$(p$-value $=0.201)$} \\
\hline \multirow{2}{*}{$\mathrm{A}_{\mathrm{L}}\left(\mathrm{cm}^{2}\right)$} & $12.2 \pm 0.5$ & $10.6 \pm 0.6$ & $17.4 \pm 0.9$ & $17.1 \pm 1.1$ \\
\hline & \multicolumn{2}{|c|}{$(p$-value $=0.022)$} & \multicolumn{2}{|c|}{$(p$-value $=0.414)$} \\
\hline \multirow{2}{*}{ LMA $\left(\mathrm{g} \mathrm{m}^{-2}\right)$} & $104.0 \pm 2.6$ & $111.5 \pm 2.9$ & $41.1 \pm 1.5$ & $41.6 \pm 1.3$ \\
\hline & \multicolumn{2}{|c|}{$(p$-value $=0.06)$} & \multicolumn{2}{|c|}{$(p$-value $=0.797)$} \\
\hline
\end{tabular}

Table 2. Mean \pm SEM ( $n=3$ plants) of total number of leaves $\left(\mathrm{N}_{\mathrm{L}}\right)$ as recorded in June (before starting drought treatment) and in July (at the end of the experimental period, for details, see the text). Different letters indicate statistically significant differences based on two-way ANOVA. F values are reported as resulted by statistical analysis of $\mathrm{N}_{\mathrm{L}}$ measurements by time, $\mathrm{T}$ (i.e., June, before drought, and July, at the end of experimental treatment) and light treatment, L (i.e., control and shaded samples).

\begin{tabular}{|c|c|c|c|c|}
\hline \multirow{2}{*}{ Species } & \multirow{2}{*}{ Time } & \multicolumn{2}{|c|}{$\mathbf{N}_{\mathrm{L}}$} & \multirow{2}{*}{$p$-Value } \\
\hline & & C & $\mathbf{S}$ & \\
\hline \multirow{2}{*}{ L. nobilis } & June & $32.3 \pm 3.5$ & $33.7 \pm 5.5$ & $\begin{array}{l}\text { T: } 0.819 \\
\text { L: } 1\end{array}$ \\
\hline & July & $32.3 \pm 3.5$ & $33.7 \pm 5.5$ & $\mathrm{~T} \times \mathrm{L}: 1$ \\
\hline \multirow{2}{*}{ P. alba } & June & $177.3 \pm 15.5 \mathrm{a}$ & $168.7 \pm 9.6 a$ & $\begin{array}{c}\mathrm{T}:<0.001 \\
\text { L: } 0.1\end{array}$ \\
\hline & July & $38.7 \pm 10.11 b$ & $95.7 \pm 3.6 c$ & $\mathrm{~T} \times \mathrm{L}:<0.05$ \\
\hline
\end{tabular}

\subsection{Plant Water Relations}

Stem shading did not affect plant water relations of the two study species. In accordance, no differences in $\Psi_{\text {tlp }}, \pi_{0}$ and $\varepsilon_{\max }$ values were recorded in C versus $S$ samples (Tables 3 and 4). L. nobilis plants lowered their $\Psi_{\text {tlp }}$ value by decreasing $\pi_{0}$ in response to drought. By contrast, no changes in these parameters were recorded in P. alba.

Midday values of $\mathrm{g}_{\mathrm{L}}, \mathrm{A}_{\mathrm{n}}$ and $\Psi_{\mathrm{x}}$ during the experimental period were statistically similar in C versus $S$ samples (Figure 2). In response to drought, reductions of stomatal aperture and photosynthetic rates were recorded. Stomatal closure did not fully prevent the drop of xylem water potential to about $-1.3 \mathrm{MPa}$, that, in turn, induced a significant loss of stem hydraulic conductivity (see below). In response to re-irrigation, $\mathrm{g}_{\mathrm{L}}$ and $\mathrm{A}_{\mathrm{n}}$ partially recovered but remained below pre-drought values. However, it can be noted that we recorded values only until 7 days after re-irrigation. Therefore, it cannot be excluded that a full recovery of gas exchange may have occurred after a longer time interval. 
Table 3. Mean \pm SEM $(n=5)$ of leaf water potential at turgor loss point $\left(-\Psi_{\text {tlp }}\right)$, osmotic potential at full turgor $\left(-\pi_{\mathrm{o}}\right)$ and bulk modulus of elasticity $\left(\varepsilon_{\max }\right)$ as recorded in June (before starting drought treatment), and in July (at the end of the experimental period) in control (C) and shaded (S) samples of L. nobilis and P. alba plants. Different letters indicate statistically significant differences based on two-way ANOVA.

\begin{tabular}{cccccc}
\hline \multirow{2}{*}{ Parameter } & \multirow{2}{*}{ Time } & \multicolumn{2}{c}{ L. nobilis } & \multicolumn{2}{c}{ P. alba } \\
\cline { 3 - 6 } & & C & S & C & S \\
\hline \multirow{2}{*}{$-\Psi_{\text {tlp }}(\mathrm{MPa})$} & June & $1.99 \pm 0.05 \mathrm{a}$ & $1.97 \pm 0.06 \mathrm{a}$ & $2.27 \pm 0.03$ & $2.21 \pm 0.10$ \\
& July & $2.64 \pm 0.11 \mathrm{~b}$ & $2.62 \pm 0.10 \mathrm{~b}$ & $2.19 \pm 0.01$ & $2.19 \pm 0.09$ \\
\hline \multirow{2}{*}{$-\pi_{\mathrm{o}}(\mathrm{MPa})$} & June & $1.71 \pm 0.04 \mathrm{a}$ & $1.72 \pm 0.04 \mathrm{a}$ & $1.73 \pm 0.03$ & $1.72 \pm 0.05$ \\
& July & $2.07 \pm 0.0 .3 \mathrm{~b}$ & $2.08 \pm 0.09 \mathrm{~b}$ & $1.53 \pm 0.11$ & $1.72 \pm 0.09$ \\
\hline \multirow{2}{*}{$\varepsilon_{\max }(\mathrm{MPa})$} & June & $27.4 \pm 3.6$ & $31.2 \pm 4.4$ & $18.2 \pm 4.5$ & $25.7 \pm 3.5$ \\
& July & $35.7 \pm 2.5$ & $37.9 \pm 3.1$ & $30.1 \pm 3.9$ & $27.6 \pm 4.1$ \\
\hline
\end{tabular}

Table 4. Results of the two-way ANOVA analysis of parameters determined from PV-curves' analysis by time of measurement, $\mathrm{T}$ (i.e., Before drought and at the end of experiment) and light treatment, $\mathrm{L}$ (i.e., control and shaded samples). Numbers represent F values; ${ }^{* * *}=p<0.001$.

\begin{tabular}{ccccccc}
\hline \multirow{2}{*}{ Parameter } & \multicolumn{3}{c}{ L. nobilis } & \multicolumn{3}{c}{ Plba } \\
\cline { 2 - 7 } & $\mathbf{T}$ & $\mathbf{L}$ & $\mathbf{T} \times \mathbf{L}$ & $\mathbf{T}$ & $\mathbf{L}$ & $\mathbf{T} \times \mathbf{L}$ \\
\hline$\Psi_{\text {tlp }}(\mathrm{MPa})$ & $\mathbf{4 3 . 5 8 * * *}$ & 0.025 & 0.0006 & 0.18 & 0.08 & 0.04 \\
\hline$\pi_{\mathrm{o}}(\mathrm{MPa})$ & $\mathbf{3 3 . 9 1 * * *}$ & 0.05 & 0.01 & 1.23 & 0.91 & 1.11 \\
\hline$\varepsilon_{\max }(\mathrm{MPa})$ & $\mathbf{3 . 7 6}$ & 0.58 & 0.05 & 2.36 & 1.30 & 1.24 \\
\hline
\end{tabular}
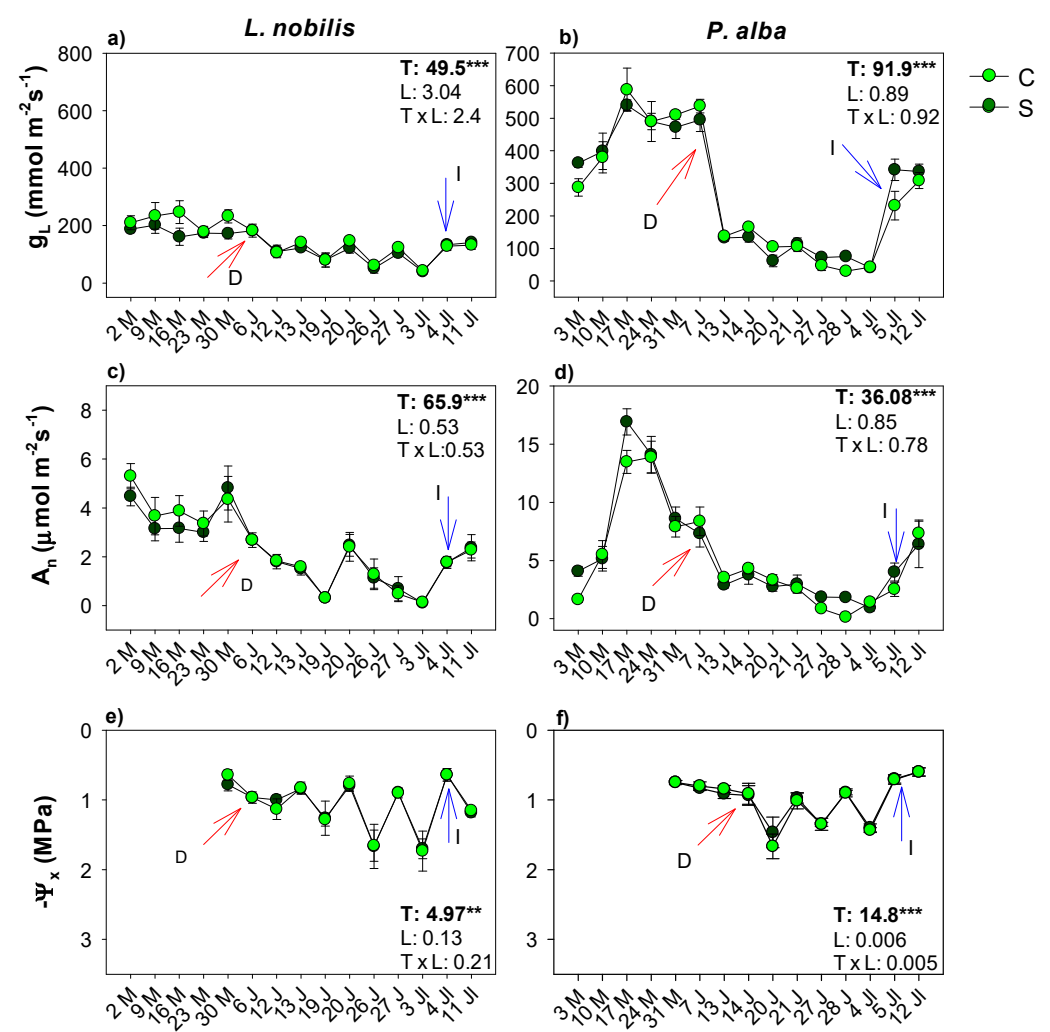

Figure 2. Mean values \pm SEM of $(\mathbf{a}, \mathbf{b})$ stomatal conductance to water vapor, $\mathrm{g}_{\mathrm{L}} ;(\mathbf{c}, \mathbf{d})$ photosynthetic rate $\left(\mathrm{A}_{\mathrm{n}}\right)$ and $(\mathbf{e}, \mathbf{f})$ xylem water potential $\left(\Psi_{\mathrm{X}}\right)$ as recorded in May $(\mathrm{M})$, June $(\mathrm{J})$ and July $(\mathrm{Jl})$ in control (C, light green circle) and shaded samples (S, dark green circle) of L. nobilis and P. alba plants. Arrows indicate the day starting drought treatment (D) and re-irrigation (I). F values, as obtained by the two-way ANOVA analysis, are reported. Time of measurement, T, and light treatment, L (i.e., control and shaded samples) are the explanatory variables ${ }^{* *}=p<0.01 ;{ }^{* * *}=p<0.001$. 


\subsection{Hydraulic Recovery and NSCs Content}

Stem shading did not affect the ability to recover xylem hydraulic function upon re-irrigation in the evergreen species, but influenced this process in the deciduous one (Figure 3). In fact, in poplar, a significant interaction between time and treatment (i.e., $\mathrm{C}$ versus $\mathrm{S}$ ) was recorded. By contrast, changes in PLC were affected only by time in laurel samples. In accordance, C and S samples of L. nobilis had PLC of about $40 \%$ at midday and about $20 \%$ on the next morning (i.e., 6:00 a.m.) while under drought stress, and of about $10 \%$ in response to re-irrigation. By contrast, despite a similar value of PLC recorded at midday in $\mathrm{C}$ and $\mathrm{S}$ samples in P. alba, only controls showed hydraulic recovery after re-irrigation.
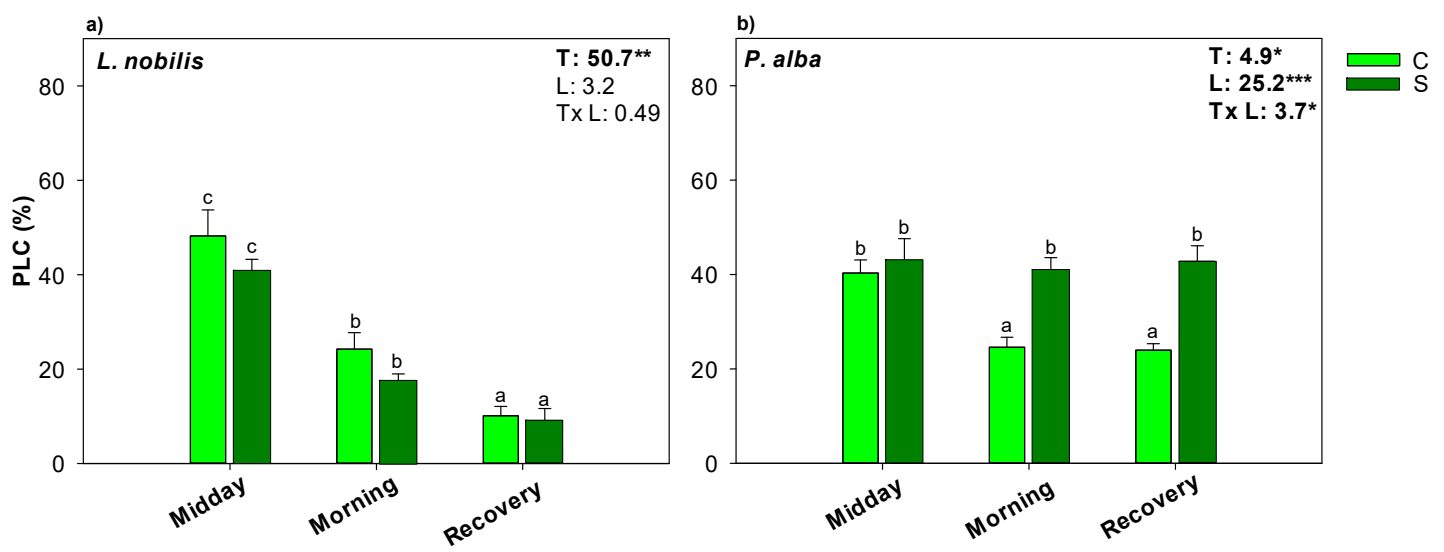

Figure 3. Mean values \pm SEM of percentage loss of hydraulic conductivity (PLC) as recorded in control (C) and shaded stem (S) samples of L. nobilis (a) and P. alba (b) as measured at midday, on the following morning (Morning) as well as in samples re-irrigated at field capacity and measured 7 days after re-irrigation (Recovery). Light green and dark green columns refer to $C$ and $S$ samples, respectively. $F$ values, as obtained by the two-way ANOVA analysis, are reported. Time of measurement, T, and light treatment, L (i.e., control and shaded samples) are the explanatory variables. ${ }^{*}=p<0.05$; ${ }^{* *}=p<0.01 ; * *=p<0.001$

Laurel and poplar samples not experiencing drought (i.e., samples collected, at the end of drought treatment, by plants maintained fully irrigated during all experimental period) showed a soluble sugar content of about $14 \mathrm{mg} \mathrm{g}^{-1} \mathrm{DW}^{-1}$, and no differences in midday versus morning values were recorded (Tables 5 and 6). Starch content was about $20 \mathrm{mg} \mathrm{g}^{-1} \mathrm{DW}^{-1}$ in L. nobilis, but only up to $10 \mathrm{mg} \mathrm{g}^{-1} \mathrm{DW}^{-1}$ in P. alba (Tables 5 and 6).

Table 5. Mean values \pm SEM of soluble NSCs and starch content as recorded in well-watered samples of L. nobilis and P. alba at midday and on the following morning on the same days of hydraulic measurements in water-stressed samples. Different letters indicate statistically significant differences based on two-way ANOVA.

\begin{tabular}{|c|c|c|c|c|}
\hline \multirow{2}{*}{ Species } & \multicolumn{2}{|c|}{$\begin{array}{l}\text { Soluble Sugars } \\
\left(\mathrm{mg} \mathrm{g}^{-1} \mathrm{DW}^{-1}\right)\end{array}$} & \multicolumn{2}{|c|}{$\begin{array}{c}\text { Starch } \\
\left(\mathrm{mg} \mathrm{g}^{-1} \mathrm{DW}^{-1}\right)\end{array}$} \\
\hline & Midday & Morning & Midday & Morning \\
\hline L. nobilis & $14.8 \pm 7.3$ & $13.2 \pm 9.7$ & $19.2 \pm 1.8 \mathrm{~b}$ & $17.9 \pm 2.5 b$ \\
\hline P. alba & $13.1 \pm 1.3$ & $13.2 \pm 1.2$ & $6.9 \pm 2.3 a$ & $610.5 \pm 2.8 \mathrm{ab}$ \\
\hline
\end{tabular}

Table 6. Results of the two-way ANOVA analysis of parameters by species, $\mathrm{Sp}$ (i.e., laurel versus poplar) and time, T (i.e., Midday versus Morning). Numbers represent F values; ${ }^{* * *}=p<0.001$.

\begin{tabular}{cccc}
\hline Parameters & Sp & $\mathbf{T}$ & Sp $\times \mathbf{T}$ \\
\hline soluble NSCs & 0.53 & 0.41 & 0.62 \\
starch & $\mathbf{1 6 . 7 1 * *}$ & 0.215 & 1.01 \\
\hline
\end{tabular}


C and S samples of both species showed similar trends of soluble NSCs' content (Figure $4 a, b$ ). Higher values of soluble NSCs were recorded at midday compared to morning and no significant differences were recorded in response to re-irrigation compared to values measured in the early morning (i.e., 6:00 am). However, in laurel, a significant interaction between time and treatment (i.e., $\mathrm{C}$ versus S) was recorded, due to a higher decrease of soluble NSCs in control in respect to shaded samples. A statistically significant increase of starch content was recorded in $\mathrm{C}$ and $\mathrm{S}$ stems of laurel in response to re-irrigation respect values recorded at midday. A similar trend was recorded in S samples of P. alba. By contrast, in C poplar stems, a significant decrease in starch content was recorded in response to re-irrigation in respect to value recorded at midday.
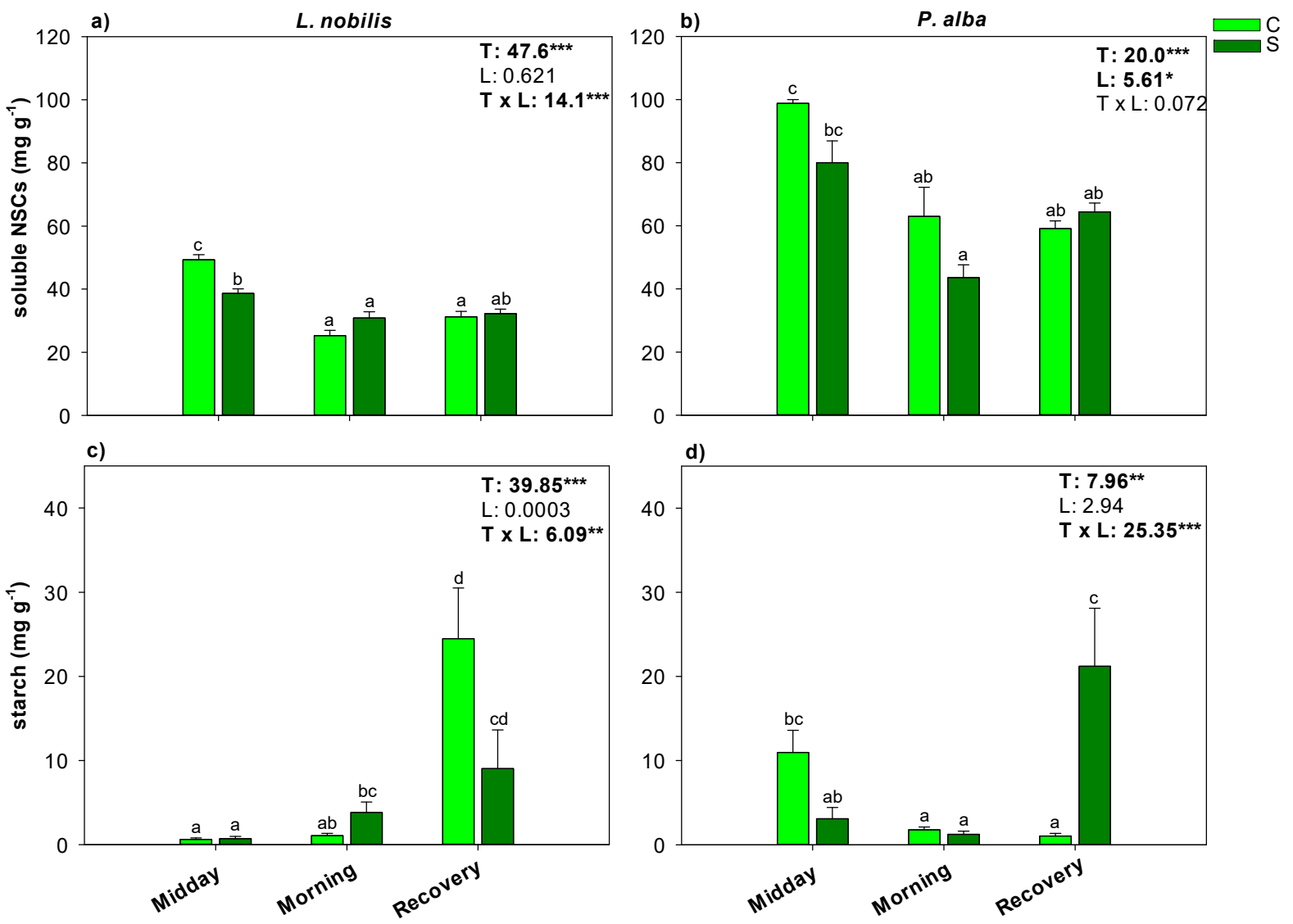

Figure 4. Mean values \pm SEM of (a,b) soluble NSCs and (c,d) starch content as recorded in control (C) and shaded stem (S) samples of L. nobilis and P. alba at midday, on the following morning (Morning) and at morning after re-irrigation at field capacity (Recovery). Light and dark green columns refer to C and S samples, respectively. F values, as obtained by the two-way ANOVA analysis, are reported. Time of measurement, T, and light treatment, L (i.e., control and shaded samples) are the explanatory variables. ${ }^{*}=p<0.05 ;{ }^{* *}=p<0.01 ;{ }^{* *}=p<0.001$.

The differences in NSC and PLC trends led to a significant relationship between starch content and the corresponding PLC values in L. nobilis but not in P. alba (Figure $5 \mathrm{c}, \mathrm{d}$ ). Moreover, a linear correlation near to be significant $(p=0.06)$ was also recorded between soluble NSCs and PLC values in laurel samples but not in poplar plants. 

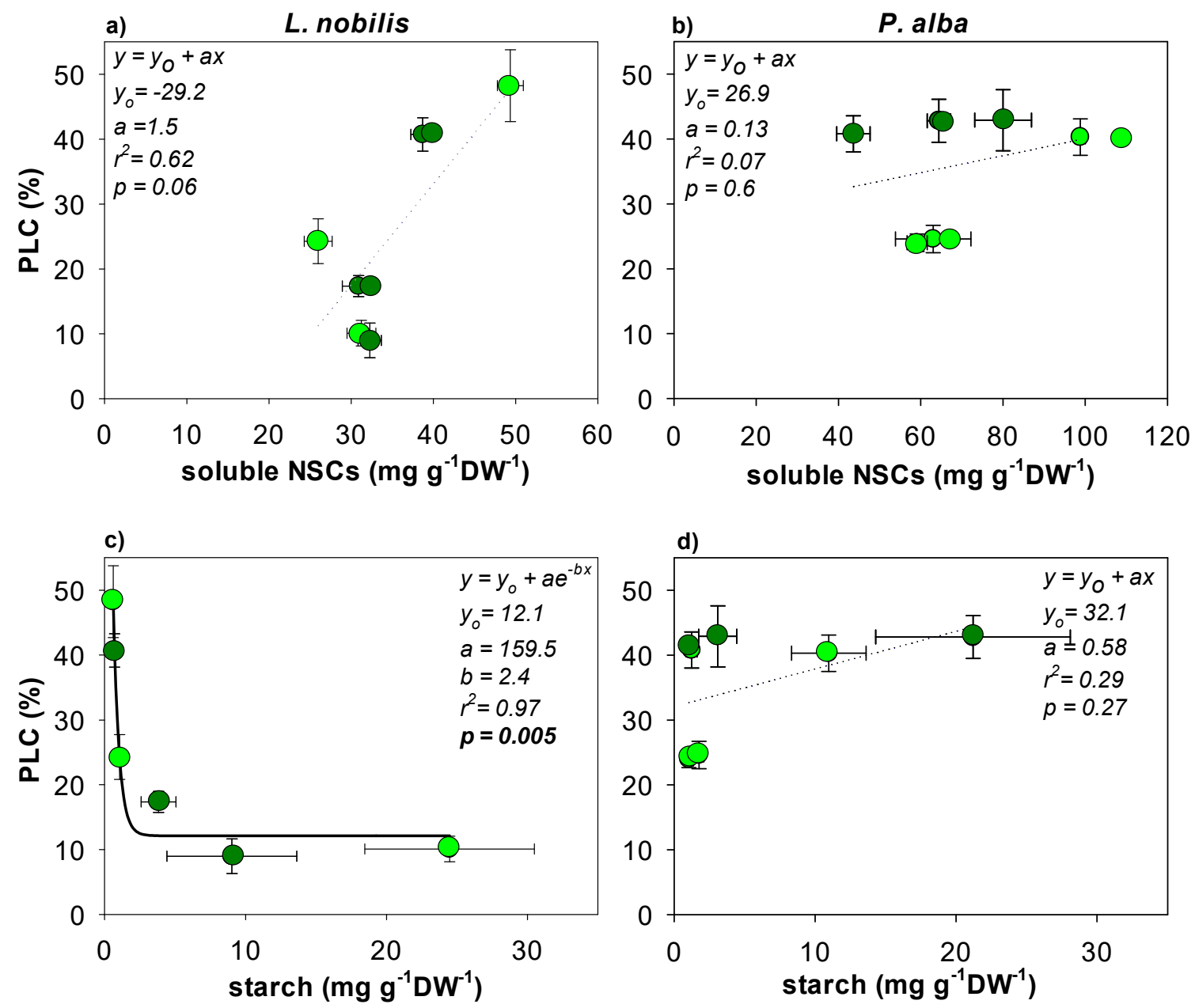

Figure 5. Relationships between percentage loss of hydraulic conductivity (PLC) and (a,c) soluble NSCs and (b,d) starch content as recorded in control (light green) and woody tissue-shaded (dark green) stem of L. nobilis and P. alba stem samples. Regression equation (dotted and solid lines for correlation with $p>0.05$ and $p<0.05$, respectively), coefficient values, correlation coefficients $\left(\mathrm{r}^{2}\right)$ and $p$-values are also reported.

\section{Discussion}

Drought-induced hydraulic failure (i.e., whole blockage of the long-distance water transport system) poses a major threat to plant survival [76,77], but even carbon starvation can represent a significant challenge to plants facing water limitations $[43,78]$. The maintenance of basal metabolism under drought, when leaf gas exchange is strongly reduced by stomatal closure, relies on the consumption of stored NSCs [39]. However, NSCs might play even more important indirect roles under drought, e.g., being involved in the maintenance of hydraulic conductance [42]. Hence, the eventual extra carbon gain assured by stem photosynthesis under drought may be involved in the modulation of plant hydraulic functions $[7,35,62,63]$. Our results support the hypothesis that stem-level carbon gain plays a species-dependent role in the post-drought hydraulic recovery $[21,35,79]$. However, only in the deciduous poplar stem shading did affect the hydraulic recovery ability, while this was not the case for the evergreen laurel.

Inhibition of stem photosynthesis did not produce effects on the growth of poplar saplings. By contrast, smaller leaves were produced by $S$ samples of L. nobilis compared to controls. Moreover, 5 weeks after the end of foliar expansion, lower starch content was recorded in well-watered samples of poplar compared to laurel (i.e., about 10 versus $20 \mathrm{mg} \mathrm{g}^{-1} \mathrm{DW}^{-1}$ ) but soluble sugars' content were similar (i.e., about $14 \mathrm{mg} \mathrm{g}^{-1} \mathrm{DW}^{-1}$ ). Overall, these results strongly suggest that in $P$. alba, the decrease in stored NSCs, required 
to maintain similar annual growth in control and stem-shaded samples, affected the residual availability of NSCs to be used for the maintenance of hydraulic function under water stress. Sprouting is mainly supported by stored NSCs produced over the previous growing seasons, especially in deciduous species [80-84]. Woody tissue carbon storage plays a key role in annual growth, as reported in a large number of species $[85,86]$. However, the impact of the remobilization of stored NSCs on the magnitude of growth is still unclear [87-89]. Recently, Klein et al. [84] reported that more than $95 \%$ of branch starch content was consumed for production of new leaves in saplings of three deciduous species (including species showing stem photosynthesis), and the recovery of carbon reserves occurred only 2-6 weeks after complete leaf expansion. On this basis, it is reasonable to suppose that, in deciduous species, even when performing stem photosynthesis, annual growth is mainly sustained by already available wood NSCs' stores. This, in turn, is expected to lead to relevant depletion of NSC reserves that may be recovered over weeks by mature leaf and, at least in some species, by stem photosynthesis. In accordance, in well- watered samples, where no stem photosynthesis inhibition occurred, lower NSCs' content was recorded in the deciduous compared to evergreen species. Therefore, the inability to recover hydraulic function following embolism build-up under drought as recorded in S poplar samples was likely the consequence of inhibition of stem photosynthesis coupled to lower NSC reserves for the maintenance of hydraulic function during water stress, compared to laurel plants subjected to the same treatment. In accordance, xylem recovery occurred in control P. alba samples that, with equal NSC reserves of $S$ samples, can rely on stem photosynthesis as well as in $\mathrm{C}$ and stem-shaded plants of L. nobilis.

In response to experimental drought, we observed a significant reduction in leaf gas exchange in the study species, leading to a severe reduction of leaf-level carbon assimilation. Under such conditions, plant metabolism of $C$ plants was probably maintained by stored carbon compounds as well as by stem photosynthesis products. By contrast, in $\mathrm{S}$ samples, only stored carbon could be used. Soluble NSCs derived from photosynthesis or by starch hydrolysis are also necessary for osmoregulation processes and/or ROS scavenging $[46-48,90]$. Sugars lead to generation of local positive pressures to drive water inflow into embolized conduits when water potential rises upon re-irrigation, leading to hydraulic recovery, i.e., [61,91-93]. In accordance, L. nobilis plants under drought showed a significant increase in soluble NSC content, and a parallel decrease in starch concentration in both C and S samples, compared to well-watered plants. Moreover, in this species, changes in NSC content were clearly related to changes in PLC. A different trend was recorded in P. alba. In fact, despite (i) the significant increase in soluble NSCs' content as recorded in $C$ and $S$ poplar samples in respect to well-watered plants and (ii) soluble sugars content showing similar trend of changes in $C$ and $S$ poplar and laurel plants in response to drought-recovery cycle, no correlation between NSCs and PLC values was recorded in P. alba. These results clearly suggest that, in poplar stems, modulation of soluble NSCs and starch content was not involved in restoring hydraulic function, at least in $\mathrm{S}$ samples, where no refilling occurred even after re-irrigation.

Our data invite to depict the following scenario, that might orient future studies on the role of stem photosynthesis in modulation of plant hydraulic functioning. In evergreens, the maintenance of leaf photosynthesis over the whole year may assure sufficient carbon uptake, so that carbon stores would be normally available and usable under stress conditions. Hence, for these species, stem photosynthesis could represent an extra carbon gain to be used only when leaf photosynthesis is severely inhibited. By contrast, in deciduous species, the extra carbon gain derived by stem photosynthesis might play a key role in whole plant metabolism, especially under drought. In these species, stem photosynthesis would not provide an "extra" carbon gain but would contribute to whole plant carbon assimilation.

\section{Conclusions}

In conclusion, our experiment has tried to disentangle the impact of leaf and stem photosynthesis on post-drought hydraulic recovery, showing that carbon assimilation at 
stem level differentially affects the maintenance of hydraulic functions in an evergreen versus a deciduous species. Our results, if confirmed in a wider number of deciduous versus evergreen species, will provide key information to predict the vulnerability of tree species under current global climate changes. Nevertheless, further studies investigating the impact of long- and short-term stem shading on species-specific drought resilience are needed.

Author Contributions: Conceptualization, P.T., A.N. and V.C.; investigation, E.A., S.G., S.N., P.T. and V.C.; resources, P.T. and V.C.; data curation, P.T.; writing—original draft preparation, P.T; writingreview and editing, P.T., A.N. and V.C. All authors have read and agreed to the published version of the manuscript.

Funding: This research received no external funding.

Data Availability Statement: The data presented in this study are available on request from the corresponding author.

Acknowledgments: We are very grateful to Dipartimento Regionale Azienda Foreste Demaniali, Messina, Sicily, Italy, for kindly providing plant material.

Conflicts of Interest: The authors declare no conflict of interest.

\section{References}

1. Wiebe, H.H. Photosynthesis in wood. Physiol. Plant. 1975, 33, 245-246. [CrossRef]

2. Van Cleve, B.; Apel, K. Induction by nitrogen and low temperature of storage-protein synthesis in poplar trees exposed to long days. Planta 1993, 189, 157-160. [CrossRef]

3. Berveiller, D.; Kierzkowski, D.; Damesin, C. Interspecific variability of stem photosynthesis among tree species. Tree Physiol. 2007, 27, 53-61. [CrossRef]

4. Rentzou, G.K.; Psaras, A. Green plastids, maximal PSII photochemical efficiency and starch content of inner stem tissues of three Mediterranean woody species during the year. Flora 2008, 203, 350-357. [CrossRef]

5. Nilsen, E.T. Stem photosynthesis: Extent, patterns, and role in plant carbon economy. In Plant. Stems; Gartner, B.L., Ed.; Elsevier: Amsterdam, The Netherlands, 1995; pp. 223-240.

6. Teskey, R.O.; Saveyn, A.; Steppe, K.; McGuire, M.A. Origin, fate and significance of $\mathrm{CO}_{2}$ in tree stems. New Phytol. 2008, 177, 17-32. [CrossRef] [PubMed]

7. Avila-Lovera, E.; Herrera, A.; Tezara, W. Contribution of stem $\mathrm{CO}_{2}$ fixation to whole-plant carbon balance in nonsucculent species. Photosyntica 2014, 52, 3-15. [CrossRef]

8. Aschan, G.; Pfanz, H. Non foliar photosynthesis-A strategy of additional carbon acquisition. Flora Morphol. Distrib. Funct. Ecol. Plants 2003, 198, 81-97. [CrossRef]

9. Ehleringer, J.R.; Phillips, S.L.; Comstock, J.P. Seasonal variation in the carbon isotopic composition of desert plants. Funct. Ecol. 1992, 6, 396-404. [CrossRef]

10. Nilsen, E.T.; Sharifi, M.R. Carbon isotopic composition of legumes with photosynthetic stems from mediterranean and desert habitats. Am. J. Bot. 1997, 84, 1707-1713. [CrossRef]

11. Avila-Lovera, E.; Tezara, W. Water use efficiency is higher in green stems than in leaves of a tropical tree species. Trees 2018, 32, 1547-1558. [CrossRef]

12. Avila-Lovera, E.; Urich, R.; Coronel, I.; Tezara, W. Seasonal gas exchange and resource-use efficiency in evergreen versus deciduous species from a tropical dry forest. Tree Physiol. 2019, 39, 1561-1571. [CrossRef] [PubMed]

13. Santiago, L.S.; Goldstein, G.; Meinzer, F.C.; Fisher, J.B.; Machado, K.; Woodruff, D.; Jones, T. Leaf photosynthetic traits scale with hydraulic conductivity and wood density in Panamanian forest canopy trees. Oecol 2004, 140, 543-550. [CrossRef] [PubMed]

14. Osmond, C.B.; Smith, S.D.; Gui-Ying, B.; Sharkey, T.D. Stem photosynthesis in a desert ephemeral, Eriogonum inflatum. Characterization of leaf and stem $\mathrm{CO}_{2}$ fixation and $\mathrm{H}_{2} \mathrm{O}$ vapor exchange under controlled conditions. Oecol 1987, 72, 542-549. [CrossRef]

15. Nilsen, E.T.; Meinzer, F.C.; Rundel, P.W. Stem photosynthesis in Psorothamnus spinosus (smoke tree) in the Sonorandesert of California. Oecol 1989, 79, 193-197. [CrossRef]

16. Nilsen, E.T.; Bao, Y. The influence of water stress on stem and leaf photosynthesis in Glycine max and Spartium junceum (leguminosae). Am. J. Bot. 1990, 77, 1007-1015. [CrossRef]

17. Tinoco-Ojanguren, C. Diurnal and seasonal patterns of gas exchange and carbon gain contribution of leaves and stems of Justicia californica in the Sonoran Desert. J. Arid Environ. 2008, 72, 127-140. [CrossRef]

18. Damesin, C. Respiration and photosynthesis characteristics of current-year stems of Fagus sylvatica: From the seasonal pattern to an annual balance. New Phytol. 2003, 158, 465-475. [CrossRef] 
19. De Roo, L.; Salomon, R.L.; Steppe, K. Woody tissue photosynthesis reduces stem $\mathrm{CO}_{2}$ efflux by half and remains unaffected by drought stress in young Populus tremula trees. Plant. Cell Enviorn. 2020, 43, 981-991. [CrossRef] [PubMed]

20. Saveyn, K.A.; Steppe, N.; Ubierna, T.E. Woody tissue photosynthesis and its contribution to trunk growth and bud development in young plants. Plant. Cell Environ. 2010, 33, 1949-1958. [CrossRef]

21. Bloemen, J.; Overlaet-Michiels, L.; Steppe, K. Understanding plant responses to drought: How important is woody tissue photosynthesis? Acta Hortic. 2013, 991, 149-155. [CrossRef]

22. Cernusak, L.A.; Hutley, L.B. Stable isotopes reveal the contribution of corticular photosynthesis to growth in branches of Eucalyptus miniata. Plant. Physiol. 2011, 155, 515-523. [CrossRef]

23. Simbo, D.J.; Van den Bilcke, N.; Samson, R. Contribution of corticular photosynthesis to bud development in african baobab (Adansonia digitata L.) and castor bean (Ricinus communis L.) seedlings. Environ. Exp. Bot. 2013, 95, 1-5. [CrossRef]

24. Liu, J.; Gu, L.; Yu, J.; Ju, G.; Sun, Z. Stem photosynthesis of twig and its contribution to new organ development in cutting seedlings of Salix Matsudana Koidx. Forests 2018, 9, 207. [CrossRef]

25. Bossard, C.C.; Rejmanek, M. Why have green stems? Funct. Ecol. 1992, 6, 197-205. [CrossRef]

26. Pfanz, H.; Aschan, G. The existence of bark and stem photosynthesis in woody plants and its significance for the overall carbon gain. An eco-physiological and ecological approach. In Progress in Botany; Essr, K., Luttge, U., Kadereit, J.W., Beyshlag, W., Eds.; Springer: Berlin, Germany, 2001; Volume 62, pp. 477-510.

27. Eyles, A.; Pinkard, E.A.; Mohammed, C. Shifts in biomass and resource allocation patterns following defoliation in Eucalyptus globulus growing with varying water and nutrient supplies. Tree Physiol. 2009, 29, 753-764. [CrossRef] [PubMed]

28. Cernusak, L.A.; Marshall, J.D. Photosynthetic refixation in branches of western white pine. Funct. Ecol. $2000,14,300-311$.

29. Pfanz, H.; Aschan, G.; Langenfeld-Heyser, R.; Wittmann, C.; Loose, M. Ecology and ecophysiology of tree stems: Corticular and wood photosynthesis. Naturwissenschaften 2002, 89, 147-162.

30. Wittmann, C.; Pfanz, H. Temperature dependency of bark photosynthesis in beech (Fagus sylvatica L.) and birch (Betula pendula Roth.) trees. J. Exp. Bot. 2007, 58, 4293-4306. [CrossRef]

31. Wittmann, C.; Pfanz, H. Bark and woody tissue photosynthesis: A means to avoid hypoxia or anoxia in developing stem tissue. Funct. Plant. Biol. 2014, 41, 940-953. [CrossRef]

32. Wittmann, C.; Pfanz, H. More than just $\mathrm{CO}_{2}$-recycling: Corticular photosynthesis as a mechanism to reduce the risk of an energy crisis induced by low oxygen. New Phythol. 2018, 219, 551-564. [CrossRef]

33. Comstock, J.P.; Ehleringer, J.R. Contrasting photosynthetic behaviour in leaves and twigs of Hymenoclea salsola, a green-twigged warm desert shrub. Am. J. Bot. 1988, 75, 1360-1370. [CrossRef]

34. Dima, E.; Manetas, Y.; Psaras, G.H. Chlorophyll distribution pattern in inner stem tissues: Evidence from epifluorescence microscopy and reflectance measurements in 20 woody species. Trees 2006, 20, 515-521. [CrossRef]

35. Vandegehuchte, M.W.; Bloemen, J.; Vergeynst, L.L.; Steppe, K. Woody tissue photosynthesis in trees: Salve on the wounds of drought? New Phytol. 2015, 208, 998-1002. [CrossRef] [PubMed]

36. Hartmann, H.; Ziegler, W.; Kolle, O.; Trumbore, S. Thirst beats hunger declining hydration during drought prevents carbon starvation in Norway spruce saplings. New Phytol. 2013, 200, 340-349. [CrossRef] [PubMed]

37. Adams, H.D.; Zeppel, M.J.; Anderegg, W.R.; Hartmann, H.; Landhäusser, S.M.; Tissue, D.T.; Huxman, T.E.; Hudson, P.J.; Franz, T.E.; Allen, C.D.; et al. A multispecies synthesis of physiological mechanisms in drought-induced tree mortality. Nat. Ecol. Evol. 2017, 1, 1285-1291. [CrossRef]

38. Hammond, W.M.; Yu, K.; Wilson, L.A.; Will, R.E.; Anderegg, W.R.L.; Adams, H.D. Dead or dying? Quantifying the point of no return from hydraulic failure in drought- induced tree mortality. New Phytol. 2019, 223, 1834-1843. [CrossRef] [PubMed]

39. McDowell, N.G.; Beerling, D.J.; Breshears, D.D.; Fisher, R.A.; Raffa, K.F.; Stitt, M. The interdependence of mechanisms underlying climate-driven vegetation mortality. Trends Ecol. Evol. 2011, 26, 523-532. [CrossRef]

40. Hartmann, H.; Trumbore, S. Understanding the roles of non-structural carbohydrates in forest trees from what we can measure to what we want to know. New Phytol. 2016, 211, 386-403. [CrossRef]

41. Nardini, A.; Savi, T.; Trifilò, P.; Lo Gullo, M.A. Drought stress and the recovery from xylem embolism in woody plants. In Progress in Botany; Canovas, F., Luttgge, U., Matyssek, R., Eds.; Springer: Berlin, Germany, 2018; Volume 79, pp. $197-231$.

42. Tomasella, M.; Petrussa, E.; Petruzzellis, F.; Nardini, A.; Casolo, V. The possible role of non-structural carbohydrates in the regulation of tree hydraulics. Int. J. Mol. Sci. 2020, 21, 144. [CrossRef]

43. Sapes, G.; Sala, A. Relative water content consistently predicts drought mortality risk in seedling populations with different morphology, physiology, and times to death. Plant. Cell Environ. 2021, 44, 3322-3335. [CrossRef]

44. Deslauriers, A.; Beaulieu, M.; Balducci, L.; Giovannelli, A.; Gagnon, M.J.; Rossi, S. Impact of warming and drought on varbon balance related to wood formation in black spruce. Ann. Bot. 2014, 33, 335-345. [CrossRef]

45. Falchi, R.; Petrussa, E.; Braidot, E.; Sivilotti, P.; Boscutti, F.; Vuerich, M.; Calligaro, C.; Filippi, A.; Herrera, J.C.; Sabbatini, P.; et al. Analysis of non-structural carbohydrates and xylem anatomy of leaf petioles offers new insights in the drought response of two grapevine cultivars. Int. J. Mol. Sci. 2020, 21, 1457. [CrossRef]

46. Sala, A.; Woodruff, D.R.; Meinzer, F.C. Carbon dynamics in trees: Feast or famine? Tree Physiol. 2012, 32, 764-775. [CrossRef]

47. Plavcova, L.; Jansen, S. The role of xylem parenchyma in the storage and utilization of non-structural carbohydrates. In Functional and Ecological Xylem Anatomy; Hacke, U., Ed.; Springer: Berin, Germany, 2015; pp. 209-234. 
48. Traversari, L.; Neri, M.; Traversi, L. Daily osmotic adjustments in stem may be good predictors of water stress intensity in poplar. Plant. Physiol. Biochem. 2020, 146, 13-22. [CrossRef] [PubMed]

49. Neuner, G. Frost resistance in alpine woody plants. Front. Plant. Sci. 2014, 5, 654. [CrossRef] [PubMed]

50. Tixier, A.; Gambetta, G.A.; Godfrey, J.; Zwieniecki, M.A. Non-structural carbohydrates in dormant woody perennials: The tale of winter survival and spring arrival. Front. For. Glob. Chang. 2019, 2, 18. [CrossRef]

51. Améglio, T.; Decourteix, M.; Alves, G.; Valentin, V.; Sakr, S.; Julien, J.; Guillot, A.; Lacointe, A. Temperature effects on xylem sap osmolarity in walnut trees: Evidence for a vitalistic model of winter embolism repair. Tree Physiol. 2004, 24, 785-793. [CrossRef] [PubMed]

52. Mayr, S.; Kartusch, B.; Kikuta, S. Evidence for air-seeding: Watching the formation of embolism in conifer xylem. J. Plant. Hydraul. 2014, 1, e0004. [CrossRef] [PubMed]

53. Mayr, S.; Ameglio, T. Freezing stress in tree xylem. In Progress Bot; Luttge, U., Canovas, F., Matyssek, R., Eds.; Springer: Berlin, Germany, 2016; Volume 77, pp. 381-414.

54. Secchi, F.; Zwieniecki, M.A. Accumulation of sugars in the xylem apoplast observed under water stress conditions is controlled by xylem pH. Plant. Cell Environ. 2016, 39, 2350-2360. [CrossRef]

55. Pagliarani, C.; Casolo, V.; Beiragi, M.A.; Cavalletto, S.; Siciliano, I.; Schubert, A.; Gullino, M.L.; Zwieniechi, M.A.; Secchi, F. Priming xylem for stress recovery depends on coordinated activity of sugar metabolic pathways and changes in xylem sap $\mathrm{pH}$. Plant. Cell Environ. 2019, 42, 1775-1787. [CrossRef]

56. Oroian, M.; Ropciuc, S.; Amariei, S.; Gutt, G. Correlations between density viscosity, surface tension and ultrasonic velocity of different mono- and di-saccharides. J. Mol. Liq. 2015, 207, 145-151. [CrossRef]

57. Losso, A.; Beikircher, B.; Damon, B.; Kikuta, S.; Schimd, P.; Mayr, S. Xylem sap surface tension may be crucial for hydraulic safety. Plant. Physiol. 2017, 175, 1135-1143. [CrossRef] [PubMed]

58. Schenk, H.J.; Espino, S.; Romo, D.M.; Nima, N.; Do, A.Y.; Michaud, J.M.; Papahadjopoulos-Sternberg, B.; Yang, J.; Zuo, Y.Y.; Steppe, K.; et al. Xylem surfactants introduce a new element to the Cohesion-Tension theory. Plant. Physiol. 2017, 173, 1177-1196. [CrossRef] [PubMed]

59. Bloemen, J.; Vergeynst, L.; Overlaet-Michielis, L.; Stepps, K. How important is woody tissue photosynthesis in poplar during drought stress? Trees 2016, 30, 63-72. [CrossRef]

60. De Baerdemaeker, N.J.F.; Salomon, R.L.; De Roo, L.; Steppe, K. Sugars from woody tissue photosynthesis reduce xylem vulnerability to cavitation. New Phytol. 2017, 216, 720-727. [CrossRef]

61. Tomasella, M.; Casolo, V.; Natale, S.; Petruzzellis, F.; Kofler, W.; Beikircher, B.; Mayr, S.; Nardini, A. shade-induced reduction of stem nonstructural carbohydrates increases xylem vulnerability to embolism and impedes hydraulic recovery in Populus nigra. New Phytol. 2021, 231, 108-121. [CrossRef]

62. Schmitz, N.; Egerton, J.J.G.; Lovelock, C.E.; Ball, M.C. Light-dependent maintenance of hydraulic function in mangrove branches: Do xylary chloroplasts play a role in embolism repair? New Phytol. 2012, 195, 40-46. [CrossRef]

63. Liu, J.; Gun, L.; Yu, Y.; Huang, P.; Wu, Z.; Zhang, Q.; Qian, Y.; Wan, X.; Sun, Z. Corticular photosynthesis drives bark water uptake to refill embolized vessels in dehydrated branches of Salix matsudana. Plant. Cell Environ. 2019, 42, 2584-2596. [CrossRef]

64. Trifilò, P.; Nardini, A.; Lo Gullo, M.A.; Barbera, P.M.; Raimondo, F. Diurnal changes in embolism rate in nine dry forest trees: Relationship with specie-specific xylem vulnerability, hydraulic strategy and wood traits. Tree Physiol. 2015, 35, 694-705. [CrossRef]

65. Tyree, M.T.; Hammel, H.T. The measurement of the turgor pressure and the water relations of plants by the pressure-bomb technique. J. Exp. Bot. 1972, 23, 267-282. [CrossRef]

66. Huckin, K.; Cochard, H.; Dreyer, E.; Le Thiec, D.; Bogeat-Triboulot, M.B. Cavitation vulnerability in roots and shoots: Does Populus euphratica Oliv., a poplar from arid areas of Central Asia, differ from other poplar species? J. Exp. Bot. 2005, 418, 2003-2010. [CrossRef]

67. Nardini, A.; Savi, T.; Losso, A.A.; Petit, G.; Pacilè, S.; Tromba, G.; Mayr, S.; Trifilò, P.; Lo Gullo, M.A.; Salleo, S. X-ray microtomography observations of xylem embolism in stems of Laurus nobilis L. are consistent with hydraulic measurements of percent loss of conductance. New Phytol. 2017, 213, 1068-1075. [CrossRef] [PubMed]

68. Sperry, J.S.; Donnelly, J.R.; Tyree, M.T. A method for measuring hydraulic conductivity and embolism in xylem. Plant. Cell Environ. 1988, 11, 35-40. [CrossRef]

69. Lo Gullo, M.A.; Salleo, S. Three different methods for measuring xylem cavitation and embolism: A comparison. Ann. Bot. 1991, 67, 417-424. [CrossRef]

70. Nardini, A.; Gascó, A.; Trifilò, P.; Lo Gullo, M.A.; Salleo, S. Ion-mediated enhancement of xylem hydraulic conductivity is not always suppressed by the presence of Ca2+ in the sap. J. Exp. Bot. 2007, 58, 2609-2615. [CrossRef]

71. Wheeler, J.K.; Huggett, B.A.; Tofte, A.N.; Rockwell, F.E.; Holbrook, N.M. Cutting xylem under tension or supersaturated with gas can generate PLC and the appearance of rapid recovery from embolism. Plant. Cell Environ. 2013, 36, 1938-1949. [CrossRef]

72. Trifilò, P.; Raimondo, F.; Lo Gullo, M.A.; Barbera, P.M.; Salleo, S. Nardini, A. Relax and refill: Xylem rehydration prior to hydraulic measurements favours embolism repair in stems and generates artificially low PLC values. Plant. Cell Environ. 2014, 37, 2491-2499. [CrossRef] 
73. Quentin, A.G.; Pinkard, E.A.; Ryan, M.G.; Tissue, D.T.; Baggett, L.S.; Adams, H.D.; Maillard, P.; Marchand, J.; Landhäusser, S.M.; Lacointe, A.; et al. Non-structural carbohydrates in woody plants compared among laboratories. Tree Physiol. 2015, 35, $1146-1165$. [CrossRef]

74. Landhausser, S.M.; Chow, P.S.; Dickman, L.T.; Furze, M.E.; Kuhlman, I.; Schmid, S.; Wiesenbauer, J.; Wild, B.; Gleixner, G.; Hartmann, H.; et al. Standardized protocols and procedures can precisely and accurately quantify non-structural carbohydrates. Tree Physiol. 2018, 38, 1764-1778. [CrossRef]

75. Yemm, E.W.; Willis, A.J. The estimation of carbohydrates in plant exctract by anthrone. Biochem. J. 1954, 57, 508-514. [CrossRef] [PubMed]

76. Choat, B.; Brodribb, T.J.; Brodersen, C.R.; Duursma, R.A.; Lopez, R.; Medlyn, B.E. Triggers of tree mortality under drought. Nature 2018, 558, 531-539. [CrossRef]

77. Hartmann, H.; Moura, C.F.; Anderegg, W.R.L.; Ruehr, N.K.; Salmon, Y.; Allen, C.D.; Arndt, S.K.; Breshears, D.D.; Davi, H.; Galbraith, D.; et al. Research frontiers for improving our understanding of drought- induced tree and forest mortality. New Phytol. 2018, 218, 15-28. [CrossRef]

78. Kanneberg, A.S.; Philips, R.P. Non-structural carbohydrate pools not linked to hydraulic strategies or carbon supply in tree saplings during severe drought and subsequent recovery. Tree Physiol. 2020, 40, 259-271. [CrossRef] [PubMed]

79. Cernusak, L.A.; Cheeseman, A.W. The benefits of recycling: How photosynthetic bark can increase drought tolerance. New Phytol. 2015, 208, 995-997. [CrossRef]

80. Karlsson, P.S. Effects of water and mineral nutrient supply on a deciduous and an evergreen dwarf shrub: Vaccinium uliginosum L. and $V$. vitisidaea L. Ecography 1985, 8, 1-8. [CrossRef]

81. Hansen, J.; Beck, E. Seasonal changes in the utilization and turnover of assimilation products in 8-year-old Scots pine (Pinus sylvestris L.). Trees 1994, 8, 172-182. [CrossRef]

82. Piispanen, R.; Saranpaa, P. Variation of non-structural carbohydrates in silver birch (Betula pendula Roth) wood. Trees 2001, 15, 445-451. [CrossRef]

83. Schadel, C.; Blochl, A.; Richter, A.; Hoch, G. Short-term dynamics of non-structural carbohydrates and hemicelluloses in young branches of temperate forest trees during bud break. Tree Physiol. 2009, 29, 901-911. [CrossRef]

84. Klein, T.; Vitasse, Y.; Hoch, G. coordination between growth, phenology and carbon storage in three coexisting deciduous tree species in a temperate forest. Tree Physiol. 2016, 7, 847-855. [CrossRef]

85. Martínez-Vilalta, J.; Sala, A.; Asensio, D.; Galiano, L.; Hoch, G.; Palacio, S.; Piper, F.I.; Lloret, F. Dynamics on non-structural carbohydrates in terrestrial plants: A global synthesis. Ecol. Monogr. 2016, 86, 495-516. [CrossRef]

86. Furze, M.E.; Trumbore, S.; Hartmann, H. Detours on the phloem sugar highway: Stem carbon storage and remobilization. Curr. Opin. Plant Biol. 2018, 43, 89-95. [CrossRef] [PubMed]

87. Carbone, M.S.; Czimczik, C.I.; Keenan, T.F.; Murakami, P.F.; Pederson, N.; Schaberg, P.G.; Xu, X.; Richardson, A.D. Age, allocation and availability of nonstructural carbon in mature red maple trees. New Phytol. 2013, 200, 1-11. [CrossRef]

88. Trumbore, S.; Czimczik, C.I.; Sierra, C.A.; Muhr, J.; Xu, X. Non-structural carbon dynamics and allocation relate to growth rate and leaf habit in California oaks. Tree Physiol. 2015, 35, 1206-1222. [CrossRef]

89. Piper, F.; Paula, S. The role of nonstructural carbohydrates storage in forest resilience under climate change. Curr. For. Rep. 2020, 6,1-13. [CrossRef]

90. Khaleghi, A.; Naderi, R.; Brunetti, C.; Maserti, B.E.; Salami, S.A.; Babalar, M. Morphological, physiochemical and antioxidant responses of Maclura pomifera to drought stress. Sci. Rep. 2019, 9, 19250. [CrossRef]

91. Salleo, S.; Lo Gullo, M.A.; Trifilò, P.; Nardini, A. New evidence for a role of vessel-associated cells and phloem in the rapid xylem refilling of cavitated stems of Laurus nobilis L. Plant. Cell Environ. 2004, 27, 1065-1076. [CrossRef]

92. Secchi, F.; Zwieniecki, M.A. Down-regulation of plasma intrinsic protein1 aquaporin in poplar trees. Is detrimental to recovery from embolism? Plant. Physiol. 2014, 164, 1789-1799. [CrossRef]

93. Trifilò, P.; Casolo, V.; Raimondo, F.; Petrussa, E.; Boscutti, F.; Lo Gullo, M.A.; Nardini, A. Effects of prolonged drought on stem non-structural carbohydrates content and post-drought hydraulic recovery in Laurus nobilis L.: The possible link between carbon starvation and hydraulic failure. Plant. Physiol. Biochem. 2017, 120, 232-241. [CrossRef] [PubMed] 